\title{
The Influence of Perceived Quality on Product Purchase Intention Through Event
}

\author{
Felicia Hanslim ${ }^{1}$, Henri Putra Jaya ${ }^{2}$, Yuliana Riana Prasetyawati ${ }^{3}$ \\ Institut Komunikasi dan Bisnis LSPR, Jakarta, Indonesia
}

\begin{abstract}
An important consideration factor for consumers to choose home appliances products is product quality. Marketing communication can be a medium for companies to convey information about products and their advantages as well as a stimulus that drives consumers to make purchases. Modena chooses event marketing communication tactics namely Culinaria Modena so consumers can know and experience first hand the quality and features of the product. The purpose of this study was to determine the effect of perceived quality on buying interest through the Culinaria Modena event. The results of the study stated that there is a strong influence between perceived quality on buying interest through events. This states that the event is a strategic marketing communication to build buying interest. It is recommended to Modena to increase the frequency of organizing Culinaria Modena and events become the main choice in marketing communication tactics.
\end{abstract}

\begin{abstract}
ABSTRAK
Faktor pertimbangan yang penting bagi konsumen untuk memilih produk home appliances adalah kualitas produk. Komunikasi pemasaran dapat menjadi sarana bagi perusahaan untuk menyampaikan informasi tentang produk dan keunggulannya serta menjadi stimulus bagi konsumen untuk melakukan pembelian. Modena memilih taktik komunikasi pemasaran event yaitu Culinaria Modena agar konsumen dapat mengetahui dan merasakan langsung kualitas serta fitur dari produk sehingga dapat membuat konsumen memiliki minat beli.. Tujuan penelitian ini untuk mengetahui pengaruh perceived quality terhadap minat beli melalui event Culinaria Modena. Hasil penelitian menyatakan bahwa terdapat pengaruh yang kuat antara perceived quality terhadap minat beli melalui event. Hal ini menyatakan bahwa event merupakan komunikasi pemasaran strategis perusahaan untuk membangun minat beli. Disarankan kepada Modena untuk meningkatkan frekuensi penyelenggaraan Culinaria Modena dan event sebagai pilihan utama taktik komunikasi pemasaran.
\end{abstract}

KEYWORDS:

Perceived

Quality,

Purchase Intention, Event, Marketing Communication

KATA KUNCI: Perceived Quality, Minat Beli, Event, Komunikasi Pemasaran

\section{INTRODUCTION}

As of June 2019, there were 5 industries in Indonesia that experienced an increase, namely the textile and apparel industry increased by $20.71 \%$, the paper and paper products industry; printing \& reproduction of recording media increased $12.49 \%$, other 
manufacturing industries; repair and installation services for machinery and equipment increased $8.31 \%$, the food and beverage industry increased $7.99 \%$, and the furniture industry rose $5.81 \%$ (Dirgantara, 2019).

The household equipment industry is one of the growing machinery and equipment industries, the increase occurred because electronic products have become a basic necessity. Household appliances such as stoves, refrigerators, washing machines to air conditioners are basic needs for every family, especially new families in Indonesia. The rise of e-commerce in the internet universe has changed the style of shopping, especially housewives, including for matters of buying cooking utensils. These kitchen products are among the most sought after by consumers when shopping via e-commerce. There are five categories that most steal the attention of e-commerce customers. Generally these items are household utensils and body care. "First, the moms \& baby category. Second, gadgets. Third, beauty and health. Fourth, household appliances, one of which is cookwares and finally, (electronic) home appliance (Kirnandita, 2017)

Stove is a compulsory device in the kitchen because it's plays an important role for serving food. Built-in stoves is the kind of gas stoves that have been trending among the households. The trend of a built-in stove is caused by the design that can be connected with the kitchen. Besides, the built-in stoves are more efficient for the space and safety. The factors of quality, design, function and efficiency support several families to choose a cooking stove.

Modena Indonesia is a large category of home appliances product that be able to maintain a leading position in their category. In fact, Modena continues to lead the market as Modena always chosen in all the large category of home appliances, especially for the middle up income households. Modena has got an award "No. 1 Best Selling in Indonesia "with a market share of $48 \%$ for the built-in stoves category according to the GfK Retail Audit based from Modena documents.

Current competition, requires companies to provide quality products and have more value as a differentiator with products from other brands. Quality is one of the factors that consumers consider before buying a product. Modena strives to sell quality products and has more value. One of them is by product standardization with SNI and ISO 9001 certification which was launched from the Modena website.

One of the factors that need to be considered in order for Modena to survive in leading the market is the quality of products that are in line with the wishes of consumers. Today, consumers are increasingly critical in considering the quality of a product. This makes Modena necessary to be able to maintain and improve the quality of the planting stove to avoid consumer dissatisfaction.

Having a quality product is not enough to make it possible for consumers to buy products. 
Today's consumers are very smart and have a tendency to know more before making purchases of household appliances. However, in electronic stores, consumers can usually only see the products on display and can operate the product after buying.

Consumer demands will satisfy the purchase of products due to the availability of various information that is easily obtained through various media, such as through the internet. This makes consumers more careful before buying a product by researching the desired products. Consumers can easily compare Modena products with other products via the internet.

To show the quality of its products, Modena opened a Flagship Store with the Experience Center concept. Through this concept, companies try to engage consumers through emotions, feelings, encourage them to think, take action, or to build communities. According to the Vice President of Customer Management Division in Modena Indonesia, Robert Widjaja, Modena wants to create a pleasant shopping experience while also inviting consumers to be wiser in choosing household devices (Fajriana, 2015). The existence of the Experience Center can convince consumers to choose a Modena cooking stove because consumers can try directly and find out more information. Modena held an event called Culinaria Modena that intend for the consumers so they can try out the features of the product directly and know the quality of the products so it can impact the purchase intention.

According to Duncan (Sukoco, 2014), one of the most effective ways to convey a brand's message is to invite customers and potential customers involve in the event. Event marketing has a big influence because of it's involvement. This is because event marketing is tend to be personal so every event that is carried out will certainly have a deep impression for everyone who join the event. According to Sumardy and Yoris Sebastian in (Sukoco, 2014), the event has a big role in marketing communication activities. Where before the event has only considered as a complement for other communication activities.

Modena introduced a new facility in 2015 called Culinaria Modena, which was a cooking center with complete facilities at the Modena Experience Center, South Jakarta. This place provides an interactive cooking class program where it used Modena products. Every month Culinaria Modena organizes cooking programs with different interesting themes. The presence of Modena Culinaria can also provide information about the buil-in stoves product which can be used as a reference in choosing a kitchen device. Culinaria Modena comes along with the social changes in the society that consider cooking activities are the part of modern lifestyle. In addition, according to Robert Widjaja (Burhanudin, 2016), Culinaria Modena also contain education to grew passion and interest for cooking that can benefit themselves and their families.

Basically, the event was organize to create a relaxed and happy mood that makes 
consumers more receptive to receive the persuasion message. The message of persuasion can affect the consumer's purchase intention in buying the Modena built-in stove. The consumer's purchase interest according to Kotler (Hidayat, Elita, \& Setiawan, 2012) is something that appear after receiving stimulation from the product that seen until finally develop the desire to purchase. According to (Keller \& Kotler, 2012) consumer perceptions be able to be formed and improved through events. One of the indirectly characteristics of event is soft selling that aims to make consumers interested in purchasing a product. To change the perception of quality, Modena held Culinaria Modena event. In this Culinaria Modena event, consumers can experience the features directly and know the quality of the built-in stoves. This can encourage the consumer 's purchase intention. From this description, the researcher is interested to conduct a research in the form of scientific work with the title "Perceived Quality Effect on the Interest in Buying Products through the Culinaria Modena Event."

Information of social life experiences were stored inside the memory furthermore used to make assessment and guidance for behavior / actions. There are two interactions between social inference and social memory. Where there are important content and process of conclusions towards the influence of the memory and important things that form and process a conclusion. In this research according to the interaction of the importance of memory in forming and processing conclusions. This theory stated that memory can guide and influence a conclusion. Factors that can influence information so it can be access inside the memory called stimulus sailence, priming, belief and expectancies, self relevance and memory organization (Hogg \& Cooper, 2007). The perceived quality variable is included in the belief and expectancies factors while the event variable be included in the priming factor.

Information that is processed directly through a social context. Some aspects of information can attract attention, involve processes, or can be very important to us. Information can be important if the stimuli that are obtained are very clear or can search for their significance only as a function of the existing context. Important information can then be stored in memory and activated when taking conclusions.

Stimuli that rarely can be more prominent / important information. Rarely are stimuli can make a greater impact on judgments and conclusions later than stimuli / information that are more often accepted.

When the information obtained is related to him. The information process obtained is more easily stored in memory because it has a relationship with him. For example, when someone who has a close relationship, he or she will tend to be more responsible and give more value in an activity compared to other people who are willing but do not have a close relationship before. This is because it has self-relevance between friendships. 
Information preparation makes some types of information easier to remember than other types. As a result, this greater accessibility can facilitate further conclusions and facilitate assessments that depend on more available information, while this can also inhibit retrieval and damage assessments that depend on information that is not available.

Preponderant accessibility in the memory cause by priming is based on experiences that have just happened or based on the frequency. Moreover, the information obtained and contained from memory also depends on beliefs and expectations that already exist in the past. Researcher doesn't put in a new information to the memory, but they combine th information to be more reliable than the experiences. The effect from this process is the relevant information is easier to remember for taking a conclusion later. When the first impression is good, then the expectation for the behavior will be consistent and easily to remember by the memory and it will be activated when taking a conclusion. Other wise, if the behavior is inconsistent, researcher will try to understand by comparing the information from other people experiences.

Activation of the information saved by memory in mind through experience can be more easily remember. The presence of an activation can affect a person's conclusion, evaluations and decisions. The second factor that affect the easiness of something being remember is frequency. Regular and continuous frequency activation can easily be remember without the external factors. Information inside the memory that is easy to remember and events that are easily imagined, influence, conclude and valuation.

Perceive quality is the customer's perception towards the overall quality or superiority of product services rather than the alternatives and it relation to it's purpose (Keller, 2013 , p. 187). Consumers are likely to apprise the quality of a product from various information that can be related to a product. According to Schiffman (2012, p. 76), perceive quality is one of the important factors when choosing a brand or a product.

Many research have tried to understand about the consumers opiniions about quality. Specific attributes of product quality is varied from one category to others. However, being consistent with the residency model, research identified the dimensions of perceived quality (Keller, 2013, p. 113): (1) Main functions and additional functions (Primary ingredients and supplementary features. (2) Reliability, durability and product services (Product reability, durability, and serviceability. (3) Effective service, efficiency and caring (Service effectiveness, efficiency, and empathy). (4) The aesthetics of a product can be mark from raw materials, sizes, shapes and colors (Style and design) (5) Pricing (Price)

The marketing communication mix consists of eight main communication models (Keller \& Kotler, 2012, p. 500), namely: (1) Advertising. All forms of nonpersonal presentations and promotions paid for ideas, goods, or services by sponsors identified through print media (newspapers and magazines), broadcast media (radio and television), network 
media (telephone, cable, satellite, wireless), electronic media (audiotape, videotape, videodisk, CD-ROM, web page), and display media (billboards, bookmarks, posters). (2) Sales promotion. Short-term incentives to encourage trial or purchase of products or services including consumer promotions (such as samples, coupons, and premiums), trade promotions (such as advertising and display allowances), and business and sales force promotions (contests for sales reps). (3) Events and experiences. Companysponsored activities and programs designed to make brand interactions related daily or specifically with consumers, including sports, arts, entertainment and non-formal activities. (4) Public relations and publicity. Programs that are directed internally at company employees or externally to consumers, other organizations, governments, and the media to promote or protect the company's image or communication of individual products. (5) Direct marketing. Use mail, telephone, fax, e-mail, or the internet to communicate directly with or request responses or dialog from certain customers and prospects. (6) Interactive marketing. Online activities and programs designed to engage consumers or prospects and directly or indirectly increase awareness, improve image, and create sales of products and services. (7) Word of mouth marketing. Person-toperson communication directly, in writing or through electronic media related to the experience of buying or using products and services. (8) Personal selling. Face to face interaction with one or more prospective buyers with the aim to make presentations, answer questions, and procure orders.

In this study, researchers will examine the Culinaria Modena event which is used to provide experience to consumers of the product and provide more in-depth information about Modena products, especially in planting cooker products.

Events and experiences including sports, arts, entertainment and charity events and informal activities that established a new brand interactions with consumers (Kotler \& Keller, 2009, p.186). The concept of the event is unlimited as an activity that commemorates matters related to religion, customs and culture only. Event has developed in according the consumer needs such as sports, product introduction exhibitions or another events (Noor, 2013). This activity also inspired the company to increase the company revenue by introduce their products.

PPM Management (Sukoco, 2014) explained that event marketing is an effective way to deliver a brand message by encouraging the customers and potential customers to be involved in an event that organized by the company. In event and experiences there are three characteristics discussed by Kotler and Keller (Keller \& Kotler, 2012, p. 492), they are: (1) Relevant, (2) Engaging, (3) Implicit.

According to Schiffman and Kanuk (2007, p. 238), purchase intention is a possibility of a consumers to purchase a products or the consumer's behaviour towards the willingness to purchase the product. Purchase intention can predict purchases, but it isn't certain that someone will make a purchase. 
Belch and Belch (2015, p. 124) purchase intention is generally based on the compatibility between the purchase motive or purchase purpose with the brand attributes or characteristics under consideration. In this research purchase intention was measured by using component indicators by Schiffman and Kanuk in (Randi, 2016). The components are: (1) Interested to search for information about products. (2) Consideration to purchase. (3) Interest to experience. (4) Desire to know about the product. (5) Desire to own the product

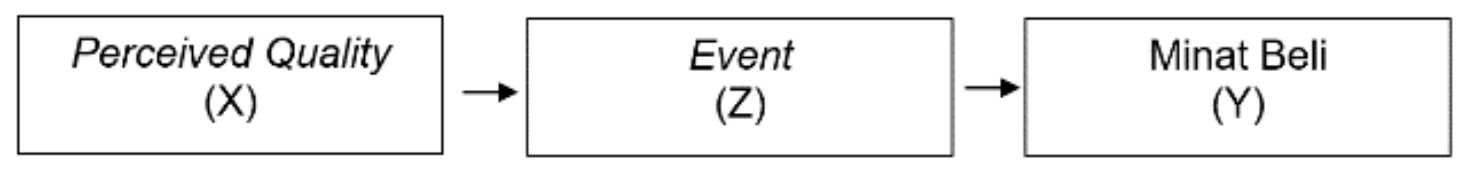

Figure 1. The Research Theory

Research Hypothesis

Ho1 : Perceived quality doesn't affect the Culinaria Modena event.

Ha1 : Perceived quality affect the Culinaria Modena event.

Ho2 : Perceived quality doesn't affect the purchase intention of the Modena built-in stove products through the Culinaria Modena event.

Ha2 : Perceived quality affect the purchase intention of the Modena built-in stove products through the Culinaria Modena event.

\section{METHOD}

The methodology used in this study is quantitative research with the type of research that is causality because research is to find out whether there is an effect of perceived quality $(\mathrm{X})$ variables on purchase intention (Y) through the event (Z). The population in this study were participants in the Culinaria Modena event which was 909 people.

In this study, researchers used simple random sampling as a sampling technique. Sugiyono (2016, p. 82) adds, it is simple because taking members of the sample from the population is done randomly without regard to the strata of the population. In determining the sample of this study, researchers used a sample determination technique with the Slovin formula (Suryani \& Hendryadi, 2015, p. 194). The researcher took a sample of 90 respondents with the desired error rate of $10 \%$. Researchers selected respondents randomly based on population data in 2017 to fill out questionnaires while attending the 2018 Culinaria Modena event. The research method used is a survey because researchers distributed questionnaires to respondents.

Data analysis technique in this study is path analysis. Path analysis is a data analysis technique using correlation and regression so that it can be known to arrive at the last dependent variable, must pass the direct path, or through an intervening variable (Sugiyono, 2016, p. 46). Researchers used variable X, namely Perceived Quality, variable 
Y, namely Purchase Intention and $\mathrm{Z}$ variable, namely Event. In this study, it will be examined whether perceived quality variables influence direct purchase intention and indirectly influence through event variables.

\section{RESULT AND DISCUSSION}

\section{Regression Error}

Regression errors in this path analysis are e1 results from the first regression and e2 results from the second regression results. The value of $\mathrm{e}$ is the root of (1-R Square) of each regression. The R Square value of the first regression, named as Perceived Quality towards Event, can be seen in the Summary Model for the regression, shown in Table 1.

\begin{tabular}{llccc}
\hline Model & $\mathrm{R}$ & R Square & $\begin{array}{l}\text { Adjusted } \\
\text { Square }\end{array}$ & $\begin{array}{c}\text { RStd. Error of the } \\
\text { Estimate }\end{array}$ \\
\hline 1 &, $705^{\mathrm{a}}$ &, 498 &, 492 & 3,812 \\
\hline a. Predictors: (Constant), $\mathrm{X}$ & & & \\
\hline
\end{tabular}

Table 1. Model of Summary Sub-Structural 1

The value of R Square is 0.498 so that the value of e1 is the square root of (1-0.449) or equals to 0.71 . This means, the amount of variance that cannot be explained by Perceived Quality towards the Event is 71\%.

\begin{tabular}{ccccc}
\hline Model & $\mathrm{R}$ & R Square & Adjusted R Square & $\begin{array}{l}\text { Std. Error of the } \\
\text { Estimate }\end{array}$ \\
\hline 1 &, $826^{\mathrm{a}}$ &, 683 &, 675 & 5,477 \\
\hline
\end{tabular}

a. Predictors: (Constant), Z, X

Table 2. Model of Summary Sub-Structural 2

The R Square value is 0.683 so, the value of e2 is the square root of (1-0.6683) or equals to 0.56 . This means, the amount of variance that cannot be explained by Perceived Quality towards the Event is $56 \%$.

\begin{tabular}{|c|c|c|c|c|c|c|}
\hline Model & & $\begin{array}{l}\text { Sum of } \\
\text { Squares }\end{array}$ & Df & $\begin{array}{l}\text { Mean } \\
\text { Square }\end{array}$ & $\mathrm{F}$ & Sig. \\
\hline \multirow{3}{*}{1} & $\begin{array}{l}\text { Regressio } \\
\mathrm{n}\end{array}$ & 1265,932 & 1 & 1265,932 & $\begin{array}{l}87,13 \\
1\end{array}$ &, $000^{\mathrm{b}}$ \\
\hline & Residual & 1278,557 & 88 & 14,529 & & \\
\hline & Total & 2544,489 & 89 & & & \\
\hline
\end{tabular}
a. Dependent Variable: Z
b. Predictors: (Constant), X

Table 3. Anova Sub-Structural 1 
Hyphothesis:

Ho1: There are no influence between perceived quality to the Culinaria Modena event. Ha1: There are some influence of perceived quality towards the Culinaria Modena event. The results of the significance test on the Anova table above shows a significance value of $0.05 \geq 0,000$. Thus, Ho is rejected and Ha is accepted (Sarjono \& Julianita, 2011, p. 132). It is proven that there is a Perceived Quality influence on Event.

\begin{tabular}{|c|c|c|c|c|c|c|}
\hline \multicolumn{2}{|c|}{ Model } & $\begin{array}{l}\text { Sum of } \\
\text { Squares }\end{array}$ & Df & $\begin{array}{l}\text { Mean } \\
\text { Square }\end{array}$ & $\mathrm{F}$ & Sig. \\
\hline \multirow{3}{*}{1} & $\begin{array}{l}\text { Regressio } \\
\mathrm{n}\end{array}$ & 5616,001 & 2 & 2808,001 & $\begin{array}{l}93,59 \\
2\end{array}$ &, $000^{\mathrm{b}}$ \\
\hline & Residual & 2610,221 & 87 & 30,003 & & \\
\hline & Total & 8226,222 & 89 & & & \\
\hline \multicolumn{7}{|c|}{ a. Dependent Variable: Y } \\
\hline \multicolumn{7}{|c|}{ b. Predictors: (Constant), Z, X } \\
\hline
\end{tabular}

Table 4. Anova Sub-Structural 2

Hyphothesis:

Ho: There are no influence between perceived quality on interest in buying Modena stove stove products through the Culinaria Modena event.

Ha: There are some influence between perceived quality on interest in buying Modena stove stove products through the Culinaria Modena event.

The results of the significance test on the Anova table above show a significance value of $0.05 \geq 0,000$. Thus, Ho is rejected and Ha is accepted (Sarjono \& Julianita, 2011, p. 132). This is evident that there is a Perceived Quality influence on Buying Interest through Event.

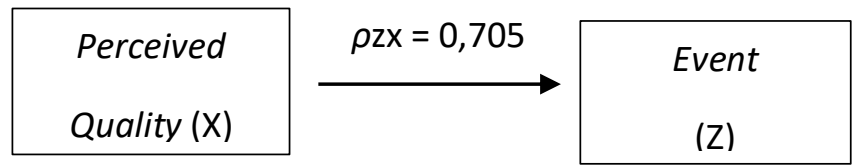

Figure 2. Sub-Structural-1

The $\rho z x$ value is the Standardized Coefficients (Beta) value obtained from the results of the first regression, namely Perceived Quality towards Event

\begin{tabular}{|c|c|c|c|c|c|c|}
\hline \multirow[t]{2}{*}{ Model } & & \multicolumn{2}{|c|}{$\begin{array}{l}\text { Unstandardized } \\
\text { Coefficients }\end{array}$} & $\begin{array}{l}\text { Standardized } \\
\text { Coefficients }\end{array}$ & \multirow[t]{2}{*}{$\mathrm{T}$} & \multirow[t]{2}{*}{ Sig. } \\
\hline & & B & Std. Error & Beta & & \\
\hline \multirow{2}{*}{1} & (Constant) & $-2,971$ & 2,948 & & \multicolumn{2}{|c|}{$-1,008,000$} \\
\hline & $\mathrm{X}$ & 0,540 & 0,058 & 0,705 & 9,334 & ,000 \\
\hline
\end{tabular}

a. Dependent Variable: $\mathrm{Z}$

Table 5. Coefficient Sub-Structural 1 
From Table 5 it can be seen that the $\rho z x$ value is the Beta parameter for Perceived Quality of Event which is 0.705 with a significance level of 0.00 or less than 0.05 so the influence is significant.

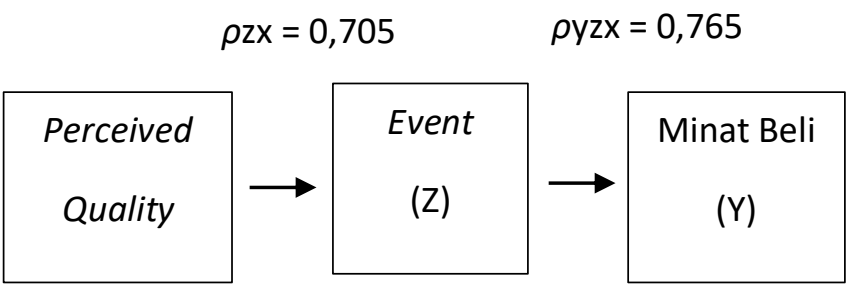

Figure 3. Sub-Structural 2.

The $\rho y z x$ value is the Standardized Coefficients (Beta) value obtained, which is Perceived Quality and Event against Purchase Interest shown in Table 6.

\begin{tabular}{|c|c|c|c|c|c|c|}
\hline & \multirow[t]{2}{*}{ Model } & \multicolumn{2}{|c|}{$\begin{array}{l}\text { Unstandardized } \\
\text { Coefficients }\end{array}$} & $\begin{array}{l}\text { Standardized } \\
\text { Coefficients }\end{array}$ & \multirow[t]{2}{*}{$\mathrm{t}$} & \multirow[t]{2}{*}{ Sig. } \\
\hline & & B & Std. Error & Beta & & \\
\hline \multirow{3}{*}{1} & (Constant) & $-4,355$ & 4,260 & & $\begin{array}{c}- \\
1,022\end{array}$ & 0,309 \\
\hline & $\bar{X}$ & 0,631 & 0,117 & 0,458 & 5,381 & 0,000 \\
\hline & $\overline{\mathrm{Z}}$ & 0,785 & 0,153 & 0,436 & 5,121 & 0,000 \\
\hline
\end{tabular}

a. Dependent Variable: $Y$

Table 6. Coefficient Sub-Structural 2

From Table 6 it can be seen that the Beta parameter for Perceived Quality against Purchase Interest is 0.458 with a significance level of 0.00 or less than 0.05 so the effect is significant. Furthermore, the Beta parameter for Event towards Purchase Interest is 0.436 with a significance level of 0.00 or less than 0.05 so the effect is significant.

\begin{tabular}{lllll}
\hline \multirow{2}{*}{ Variable } & Path Coefficient & \multicolumn{3}{c}{ Influence } \\
\cline { 3 - 5 } & & \multicolumn{2}{c}{ Direct } & \multicolumn{1}{c}{ Indirect } \\
\hline $\mathrm{X}->\mathrm{Z}$ & 0,705 & 0,705 & - & 0,705 \\
\hline $\mathrm{X}->\mathrm{Y}$ & 0,458 & 0,458 & $\begin{array}{l}0,705 \times 0,436 \\
=0,307\end{array}$ & 0,765 \\
\hline $\mathrm{Z}->\mathrm{Y}$ & 0,436 & 0,436 & - & 0,436 \\
\hline
\end{tabular}

Tabel 7. Test Result of The Influence of Path Analysis

Discussion

The accepted hypothesis are:

Ha1 : There are some influence of perceived quality towards the Culinaria Modena event. 
Ha2 : There are some influence of perceived quality towards the interest in buying Modena cooking stove products through the Culinaria Modena event.

\section{Sub-structural discussion 1}

The findings in this study indicate that there is a strong influence between perceived quality towards the Culinaria Modena event. Factors of belief and expentancies in the Social Inference and Social Memory theory stated, in addition to the new experience, the information contained in memory also depends on previous beliefs and expectations. This states that someone will add information to memory and combine with previous experience. The effect of this processing is that the relevant information becomes easier to remember.

Stimulation received by consumers are different in how each consumer knows, chooses, manages and interprets are very individual process based on internal factors such as trusts and expectations.

When the perception of Modena's cooking stove products is good, the expectation of behavior will be consistent and easy to remember in memory. If the previous perception was not good, but get additional information from the experience, consumers will compare the information from other people who had experienced it before, so the consumers can draw conclusions later.

\section{Sub-structural discussion 2}

The findings in this study indicate that there is a strong influence between perceived quality towards interest in buying Modena stove products. Perceived quality in the Social Inference and Social Memory theory, included in belief and expectancies factors that can influence later conclusions. In this study, the conclusions that has been formed were interest in buying products. Factors of belief and expentancies in Social Inference and Social Memory theory stated that consumers will process the information obtained and contained in memory to draw conclusions. When the perception of Modena's cooking stove products are good, the expectation of behavior will be consistent and easy to remember in memory. This means that the perceived quality that is owned by the consumer is very important to draw conclusions about having an interest in buying the product of the cook top.

In this study it can be seen that there is a strong influence between the event towards the interest in buying Modena stove products. Events in the Social Inference and Social Memory theory, included in priming factors that can influence later conclusions. In this study, the conclusions formed were interest in buying products. The priming factor in the Social Inference and Social Memory theory stated, through experience, stored information can be easier to remembered. In addition, experience with regular and continuous frequency can easily be remembered without the need of external factors. Information in consumer memory that is easy to remember and events that are easily 
imagined can influence conclusions and judgments. This means that the Culinaria Modena event experienced by consumers is very important to draw conclusions in the form of buying interest in cook top products.

Meanwhile the perceived quality (X) effect towards buying interest (Y) through event (Z) can be known through the perceived quality $(X)$ path coefficient multiplication of the event (Z) with the event (Z) path coefficient on buying interest (Y) and added 0.458 which is a direct influence between perceived quality (X) on buying interest $(\mathrm{Y})$. So, it produces 0.792. According to Riduwan and Kuncoro (2011), if the path coefficient interval is $>0.3$, the effect is strong. Thereby, this proves that the event adds a strong influence between perceived quality towards buying interest.

According to the Social Inference and Social Memory theory, memory can influence conclusions. In this study, memory is formed through perceived quality and event so, it can influence consumers to have an interest in buying Modena stove products. This is supported by priming factors, belief and expectancies.

With good perceived quality, it can change conclusions, especially when it is supported by the experience that has just happened. The Culinaria Modena event provides an experience that is easily remembered by consumers. If it is added with a high frequency in participating in the event it will be easier to remembered. Consumers combine information obtained from perceived quality and events so, they are more trusted and more confident. The effect of this processing is that the information obtained becomes relevant so that it is easier to remember to have an interest in buying Modena stove products.

\section{CONCLUSION}

From the results of the analysis and discussion that have been described, the followings are the conclusion of the problem and the purpose of this study. The conclusions of this study are : There is a strong impact between perceived quality towards Culinaria Modena event with 0,705 . There is a strong impact between perceived quality on purchase intention through Culinaria Modena event with 0,765 . This proves that the event $(\mathrm{Z})$ adds to the perceived quality $(\mathrm{X})$ influence towards purchase intention (Y).

For further research, it is recommend to examine other factors contained in Social Inference and Social Memory theories such as stimulus sailence, self relevance and memory organization. In this study it was found that the event can support someone to have product purchase intention because of the information and experience gained through the event. The experience gained allows consumers to feel directly a product so as to provide confidence to have purchase intention. It is not only through information but also from experience that can help determine the final conclusion that is purchase intention. 
Based on the results of the study, it was suggested to Modena to increase the frequency of the Culinaria Modena event because it could support purchase intention seen from its have strong impact. Increased frequency can make consumers remember products without external factors. With the Culinaria Modena event, where consumers can experience the Modena stove directly, it also can have a positive impact if they previously had a bad perception about Modena. In addition, it also needs to be improved in response to responding to consumers in direct services and social media so as not to create a bad perception of Modena.

\section{REFERENCES}

Belch, G.E. dan Belch, M. A. (2015). Advertising and Promotion: An Integrated Marketing Communications Perspective. Singapore: McGraw Hill Education.

Burhanudin, T. (2016, November 15). Edukasi Konsumen Melalui Cooking Centre. Dipetik Oktober 9, 2017, dari marketing.co.id: http://www.marketing.co.id/edukasikonsumen-melalui-cooking-center/.

Dirgantara, A. (2019). Pertumbuhan Industri di Indonesia Merangkak Naik. Dipetik 14 Juni 2020, dari okezone.com https://economy.okezone.com/read/2019/10/15/

Fajriana, M. (2015, November 6). Sesuaikan Furnitur Dapur Sebelum Membelinya. Dipetik Oktober 15, 2017, dari lifestyle.liputan6.com: http://lifestyle.liputan6.com/read/2358294/sesuaikan-furnitur-dapursebelum-membelinya

Hidayat, A. T., Elita, F. M., \& Setiawan, A. (2012). Hubungan Antara Atribut Produk Dengan Minat Beli Konsumen. E-jurnal Mahasiswa Universitas Padjadjaran Vol.1 No.1, 114.

Hidayat, F. (2016, Desember 22). Kompor Tunggu Kuningan Dinilai Lebih Tahan Lama. Dipetik Oktober 15, 2017, dari beritasatu.com: http://www.beritasatu.com/properti/405993-kompor-tungku-kuningan-dinilailebih-tahan-lama.html

Keller, K. L. (2013). Strategic Brand Management (4th ed.). England: Pearson Education Limited.

Keller, K. L., \& Kotler, P. (2012). Marketing Management (14th ed.). England: Pearson Limited Education. 
Kirnandita, P. (2017). Alat Masak Jadi produk Laris di e-Commerce. Dipetik 15 Juni 2020 dari tirto.id https://tirto.id/alat-masak-jadi-produk-paling-laris-di-e-commerce

Noor, A. (2013). Manajemen Event. Bandung: Alfabeta.

Randi. (2016). Pengaruh Citra Merek Terhadap Minat Beli Pada Makanan Fast Food Ayam Goreng (Studi Pada Konsumen Texas Chicken Pekanbaru). JOM FISIP Vol.3 No.2, 4.

Republika, R. (2015, November 23). Coba Dulu, Baru Beli. (s. livikacansera, Editor) Dipetik Oktober 15, 2017, dari republika.com: http://www.republika.co.id/berita/koran/belanja-koran/15/11/23/ny9igg18coba-dulu-baru-beli.

Riduwan, \& Kuncoro, E. A. (2011). Cara Menggunakan dan Memakai Path Analysis (Analisis Jalur). Bandung: Alfabeta.

Schiffman, L. G., \& Kanuk, L. L. (2007). Consumer Behavior. USA: Pearson.

Sciffman, L. G., Kanuk, L. L., \& Hansen, H. (2012). Consumer Behavior: A European Outlook. England : Pearson Education Limited.

Sugiyono. (2016). Metode Penelitian Kuantitatif, Kualitatif dan R\&D. Bandung: Alfabeta.

Sukoco, M. H. (2014). Pengaruh Pemasaran Event Terhadap Citra Merek Minuman Isotonik Mizone Di Surabaya. Jurnal Ilmu Manajemen Volume 2 Nomor 3, 748 - 758.

Suryani, \& Hendryadi. (2015). Metode Riset Kuantitatif : Teori Dan Aplikasi Pada Penelitian Bidang Manajemen Dan Ekonomi Islam. Jakarta: Kencana.

Wijanarko, R. T. (2016, Desember 8). Penjualan TV Stagnan, Home Appliances Akan Tumbuh di 2017. Dipetik Oktober 2009, 2017, dari marketeers.com: http://marketeers.com/penjualan-tv-stagnan-home-appliances-akan-tumbuhdi-2017/. 